\title{
Rónay Zoltán: Jogszerűség és etika a tanári pályán
}

\section{Fenyődi Andrea}

\author{
Eötvös Loránd Tudományegyetem Tanító- és Óvóképző Karának \\ tanársegéde \\ fenyodi.andrea@tok.elte.hu
}

Rónay Zoltán (2018). Jogszerüség és etika a tanári pályán. Budapest: ELTE Eötvös Kiadó. p. 300

DOI: 10.37205/TEL-hun.2019.3-4.12

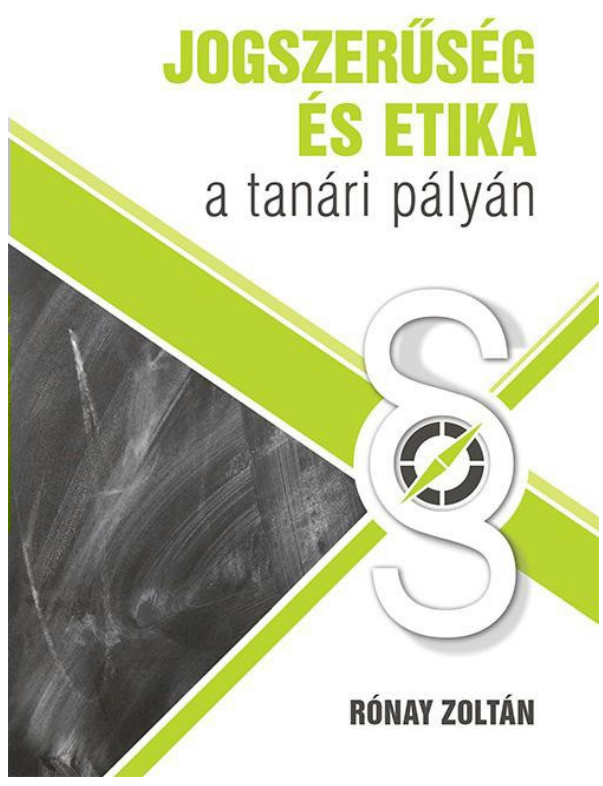

Az Eötvös Kiadó gondozásában, 2018-ban megjelent kiadványt szerzője a tanári pályával kapcsolatban lévő vagy az iránt érdeklődő olvasóknak ajánlja. Elsősorban pedagógusok, leendő pedagógusok és tanárképzésben oktatók hasznosíthatják akár jegyzetként, akár ismeretterjesztő, tájékoztató kiadványként. Bár a tanári szakmai tudás elengedhetetlen része bizonyos szintü jogi ismeret - ahogy ez a képzési és kimeneti követelményekben, és ezáltal a felsőoktatási programokban is szerepel -, a megfelelö értelmezésre a képzésekben általában kevés hangsúly kerül, és csekély idő jut. A jogi nyelvezet hiányos ismerete hátrányt jelent mindazoknak, akik a köznevelés folyamatosan változó szabályozásában szeretnének eligazodni.

Rónay Zoltán könyvében az intézményi oktatás-nevelés minden területét és aspektusát szemügyre veszi, nemcsak jogi szempontból, hanem - kisebb mértékben - etikai szempontból is. Ez a kettősség részben a szabályozó dokumentumok jellegéből fakad: a különböző törvényi szintű jogszabályok mellett a pedagógusok etikai kódexe is meghatározza a munkavállalókkal szembeni elvárásokat. A szerző szigorú jogi logikával elemzi a szabályozást, következetesen rámutat egyes értelmezésbeli ellentmondásokra vagy hiányosságokra. Ezáltal az olvasó a jog termé- 
szetét és alapfogalmait, struktúráját is jobban megérti, a munkavállaló pedig felkészültebb lehet az ellentmondásokból eredő problémákra.

A jog és az etika a jog és az etika kapcsolatának hangsúlyozása azonban nem csak a dokumentumok szintjén jelenik meg. Az iskola, a köznevelési intézményrendszer napi gyakorlata emberi interakciók ezreit generálja, amelyek folyamatos megítélésnek vannak kitéve, mind a bennük résztvevők, mind a környezet részéről. Az interakciók tágabb kereteit a törvényi szabályozás adja, de konkrét esetekben csak ritkábban ítélünk jogi szempontból, gyakrabban etikai szempontból. Ugyanakkor az etikai elvek kapcsolódnak az általános emberi jogokhoz. A szerző példák bemutatásával törekszik arra, hogy a hétköznapi esetekben is észrevegyük a jogi vagy az etikai tartalmat. Bár ezek gyakran átfedésben vannak, néha pedig egyes fogalmak nem értelmezhetőek egyértelműen, az olvasó jogi és etikai érzékenysége növekszik: jobban megérti, hogy egy-egy viselkedésmódnak, cselekedetnek milyen sokrétü következménye lehet.

Az eddig említetteken túl még egy jelentős értéke van a könyvnek. A középpontban a pedagógus áll, az ő viszonyai az oktatás-nevelés szereplőihez a rá vonatkozó elvárások, a munkahelyi környezet komplex rendszerében. Mellette megjelenik a másik legjelentősebb szereplő, a tanuló - különösen a nem nagykorú tanuló -, az ő jogi helyzetének értelmezésében is segít a kötet. A szerző határozottan kiáll a gyerekek, tanulók jogai, mégpedig alapvető jogai mellett. Visszafogottan, de elkötelezetten emeli ki, hogy ezekből a jogokból nem lehet engedni, a gyermeki jogok figyelembevételének mint szemléletnek a pedagógusok munkájának egészét át kell hatnia.

A kiadvány számtalan gyakorlati jellegű témát is érint, ami a pedagógust mint munkavállalót segíti, tudatosabbá teszi, felkészülve különböző munkaügyi, munkajogi helyzetekre. Erre a tudásra minden szakma képviselőjének szüksége lenne. Rónay Zoltán pontos, következetes gondolatvezetéssel, ugyanakkor érthető nyelvezet használatával vezeti az olvasót.

A könyv témájából adódik, hogy a kézirat zárása óta több jogszabály megváltozott a köznevelésben. Emiatt az olvasó arra is rákényszerül, hogy ellenőrizze az aktuális helyzetet, folyamatosan kövesse ezt a folyamatot.

\section{A kiadvány tartalma és szerkezete}

A kötet három fejezetből áll. Az „Alapvetések”-ben a szerző arra vállalkozik, hogy a tárgyalt fogalmi rendszert megismertesse az olvasóval. Mintegy bevezetőként a 
címben szereplő két fogalom, a jog és az etika értelmezésével kezdi, majd jogi szabályozási környezet bemutatásával a vonatkozó törvényeket mutatja be, kitérve ezek hierarchiájára. Ezután egyes jogi fogalmakat definiál, amelyekre a későbbiekben szükség lesz. A harmadik részben az etikai vonatkozásokkal foglalkozik részletesebben: az etikai kódex elemzésével és kritikus értelmezésével.

Szűkebbre mért a második fejezet, amelynek címe "Az iskola mint szervezet". Az intézmények alapításának, megszüntetésének módját, fenntartási és működtetési jogait, a különböző szereplők jogosítványait és az intézménytípusokat tárgyaló fejezetben a szerző áttekintésre törekszik, ám rávilágít a szabályozásból eredő bizonytalanságokra és ellentmondásokra is. Értelemszerűen ez az a része a múnek, ahol leginkább észrevehetők a kiadás óta eltelt változások a szabályozásban például a közalkalmazottak körének módosítása. A szakképző iskolák rendszere kevesebb hangsúlyt kap, holott egyre jobban elválik a köznevelési rendszer és a szakképzés, felnőttképzés.

A kiadvány több mint felét teszi ki a harmadik fejezet, amely az iskoláról "mint emberek közösségéről" szól. Változatos témájú alfejezetek olvashatók, amelyekben újra megjelenik az etikai nézőpont (viselkedés, kapcsolatok, agresszió, visszaélés), az alapvető személyiségi jogok és gyermekjogok megjelenése, illetve sérelme a különböző szereplők közti viszonyokban, a pedagógus munkajogi helyzete és a tanulói jogviszonyból eredő következmények, valamint fegyelmi és felelősségvállalási kérdések.

A kiadvány mintegy 300 oldal. Hivatkozott bibliográfiája magyar és nemzetközi szakirodalmat tartalmaz. Ezek közül különösen értékesek azok, amelyek olyan valós pedagógiai eseteket tartalmaznak, amelyek etikai, pedagógiai vagy jogi szempontból elemezhetőek, egyben pedig képet adnak az oktatásról vagy a gyermekek helyzetéről. Ilyenek például az oktatási jogok biztosának éves jelentései. A szakirodalom ezen kívül a fogalmak sokoldalú - jogi, pedagógiai és etikai - megértését segítő, valamint a törvényi szabályozást értelmező műveket tartalmaz.

A hivatkozott törvények és más szabályozók a rövidítések között jelennek meg, szerencsés lett volna külön listába is szedni őket, bemutatva, mely törvényekre kell a későbbiekben is tekintettel lennie a pedagógusnak. Tizenegy törvény és négy rendelet (a NAT is rendeletnek számít), valamint két helyi szabályozó (pedagógia program és szervezeti és működési szabályzat) jelenik meg, ezen kívül az Alaptörvény és a Nemzeti Pedagógiai Kar etikai kódexe. 


\section{A kiadvány szerepe a pedagógusképzésben}

Oktatóként azt tapasztalom, hogy a hallgatók a képzés vége felé, a hosszú gyakorlatok idején szembesülnek igazán azzal, hogy a „valódi élet” milyen új kihívásokat tartogat, milyen, eddig nem tapasztalt feladatokat kell megoldani. A tanárképzés részben igyekszik modellezni a pedagógiai helyzeteket, részben valós gyakorlatot kínál, de a munkavállalói aspektus még nem jelenik meg. A hallgatók védett helyzetben tanulnak és tanítanak, ám a végzés közeledtével egyre jobban hiányolják azt a tudást, amire korábban nem volt szükségük: a jogi felelősség és a jog szabályozta lehetőségek ismereteit. Ilyen ismereteket nyilvánvalóan nyújt a képzésük, de egyrészt nem jut rá annyi idő, amennyi szükséges lenne ilyen anyag megértéséhez és elsajátításához, másrészt helyzetüknél fogva a hallgatók kevésbé motiváltak lehetnek.

A bemutatott könyv azonban jó alap lehet a tanuláshoz. Irreális elvárás lenne az, hogy a hallgatók mindent megjegyezzenek, de arról teljes képet kaphatnak még ha először ijesztő is lehet -, milyen sok területre kell figyelniük a pályán. Pedagógiai döntések, mindennapi viselkedés, szülőkkel való kapcsolattartás, szabadság és betegállomány, szerződések és felmondás, fizetés, hierarchia, munkaköri leírás - ezek egy részéről más kurzusokon is tanulnak, a gyakorlaton hallanak. A könyvet a későbbiekben tájékoztató forrásként használhatják: konkrét esetekben táblázatok, példák, jogszabályokra történő utalások segítenek ebben.

A könyv sok példával és fogalomértelmezéssel segíti a megértést. A bonyolultabb rendszereket táblázatokkal, ábrákkal mutatja be. Az olvasók, különösen a hallgatók számára azonban hasznos lenne több összefoglaló ábra - ezek kissé egyenetlenül jelennek meg a kiadványban -, és további példák, esetek, valamint értelmező szószedet.

Rónay Zoltán hiánypótló, gazdag mủvet írt, amelyet érdemes megismernie a köznevelésben és a pedagógusképzésben dolgozó szakembereknek. Az oktatók sokrétủen használhatják: az alapvető tartalmakon túl például esetleírások és -értelmezések forrásaként, továbbá a tanári szerep összetettségének megmutatására, az iskolai gyakorlat előkészítésére. A hallgatók pedig jól értelmezhető anyagot kapnak, amely segíti őket felkészülni az önálló munkavállalásra. 